\title{
UK government urged to drop 'annuality' requirement
}

\section{London}

THE British government is being strongly urged to relax spending controls over the research councils to enable them to operate within a more flexible financial regime that would allow more efficient management of resources and encourage new kinds of commercial involvement. The government has been presented with two unpublished reports that highlight the problems posed when the research councils are faced with traditional Treasury restraints, particularly the system of 'annuality', which requires the councils to spend all their income from government and non-government sources within the financial year in which it is received.

The Advisory Board for the Research Councils (ABRC), whose principal job is to recommend the distribution of funds among the five research councils, commissioned a study from Sir Ralph Riley, a former secretary of the Agricultural and Food Research Council, to examine the ways in which Treasury controls were frustrating research councils' efforts to secure value for money from their funds. Similar issues have been addressed by a resource management study, undertaken by the Department of Education and Science and the research councils.

ABRC says that if the government wants public institutions to be more business-like, "the traditional public accounting limits and controls, on the councils in particular, need to be correspondingly redesigned and reduced".

The annuality problem becomes particularly acute with earnings from non- government sources, which are usually paid in arrears, where liquidity is needed to hire staff, initiate work and carry it through to the first payment. Riley recommends that councils be allowed to build up reserves from their commercial earnings.

Annuality has always been a thorn in the side of many public bodies, but ABRC says that if the research councils are to respond to stated government policy of

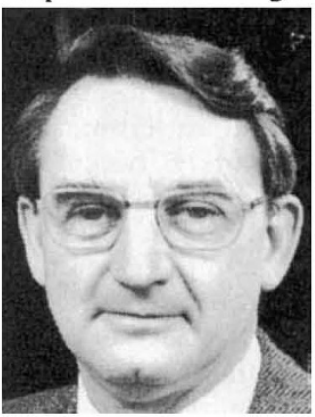
increasing earnings from external sources, some relaxation of this rule is essential. The Treasury will almost certainly attempt to resist such moves, despite its contention that it is not "in principle" against Sir Ralph Riley, author of flexibility. The anthe ABRC report. nuality rule, says the Treasury, was arrived at by "bitter experience", and is the only realistic way to provide a framework in which to operate spending control and allow accurate forecasting, given that public expenditure as a whole is determined on a yearly basis. It points out the flexibility that already exists, including a 3 per cent annual leeway for the Medical Research Council's grants provision and 4 per cent for international subscriptions, to allow for fluctuations in exchange rates. "But you can go too far down that road", said an official, "there is only so much room for latitude."

\section{Final blow to UK space plan}

\section{London}

Hopes for an expanded British space effort have been dealt a severe blow with the announcement that the government will not provide any new money for the British National Space Centre (BNSC), a body set up in 1985 to coordinate the nation's space policy. The decision will result in Britain having less of a stake in the European Space Agency (ESA), and will almost certainly mean a reduction in the domestic science programme. BNSC's last hope lies with the newly formed Advisory Council on Science and Technology (ACOST), which meets in September.

Last year, BNSC presented to the government its 15-year national space plan, which remains unpublished but is believed to have requested an annual budget of $£ 300$ million, bringing Britain's spending on civilian space to about half that of France or West Germany. BNSC itself does not directly receive funding from the Treasury; instead, its budget ( $£ 112$ million this year) is made up of the space funds of the Department of Trade and Industry ( $£ 64$ million), the Science and Engineering Research Council ( $£ 30$ million), the Ministry of Defence ( $£ 17$ million) and the Natural Environment Research Council ( $£ 1$ million). About $£ 80$ million goes to ESA, with the remainder on the domestic programme.

BNSC had hoped that the extra $£ 200$ million would come from central government. Now it is faced with the almost impossible task of trying to win a larger share of the existing civil research and development budget of $£ 4,500$ million.

In response to a question in the House of Commons on 23 July, Mrs Thatcher said that no new money would be forthcoming "at present", and that the relevant ministries had not agreed to transfer resources from existing programmes. She then suggested the by now familiar panacea: "I hope that the private sector, if interested in the results of such research, will come forward with considerable resources."

Industrialists and academics have been angered by the decision. BNSC officials are putting on a brave face and saying that the space plan has not yet been rejected outright. Space experts say that Britain needs at least $£ 200$ million a year to maintain a viable domestic programme and benefit from international collaboration.

Earlier this year, BNSC's director general, Roy Gibson, concluded a lecture by asking the government an open question: "We have the competence, we have the experience and we have the necessary enthusiasm and faith - may we please have the money?" Mrs Thatcher has answered.
Simon Hadlington 